\title{
The Construction of Innovation Education System of Second Classroom in Local Normal Colleges
}

\author{
Cui Liping \\ School of Literature, Baicheng Normal University, Baicheng 137000, China \\ email:cui4xj@126.com
}

Keywords: Normal Colleges; Second Classroom; Innovation System; Construction

\begin{abstract}
With social progress, people's own cultivation and cultural level has been continuously improved, more and more people begin to pay close attention to the problem of education. The core of education reform is the reform of personnel training mode, and teachers are the main force of personnel training, local normal colleges are the places to convey teachers for elementary education, therefore, it is very important that how to construct the innovation education system of the second classroom according to the actual situation and adapt to the diversified demands of the personnel training.
\end{abstract}

\section{Introduction}

With the development of core literacy, core literacy education is already one of the key contents of education and its main emphasis is to focus on cultivating students' lifelong development needs and abilities, that is a severe test of education, but also put forward higher requirements for teachers. Local normal university is the cradle of training teachers. In order to adapt to the development of the times, the local teachers colleges need to change the cultivation of normal school students. Through the establishment of innovation of the second classroom education system, promote the students virtue, wisdom, body, beauty and comprehensive development, and improve the quality of personnel training, improve the personnel training system is worth to explore the topic.

\section{The significance and Function of the Second Classroom}

The second classroom activities refers to the use of spare time, under the guidance of teachers, according to the interests and hobbies of the students, a series of innovative practice for cultivating and improving the comprehensive quality of the students. The second classroom includes academic competitions, cultural activities, social practice, public service, scientific research project, the results of content etc. The second classroom activities plays an important role to improve students' moral cultivation, perfect knowledge of the students in the class, enhance students' ability to adapt to society.

The Second Classroom is the Supplement and Extension of the First Class. The first class in normal universities is mainly to compare the traditional way of teaching. In the first class, the teacher will learn the professional knowledge, classroom knowledge density, rigorous curriculum, strong theoretical teaching content, teaching mode is monotonous, the student experience and interdisciplinary knowledge is relatively small, neglected the cultivation of the innovative ability of students. Teachers and second classroom activities to practice innovative learning activities, flexible, relatively involves more widely, the combination of theory and practice, time and place of randomness, is the first class good to expand and extend, promote the cultivation of students' innovative ability.

Second Class can Promote the Normal Students to Adapt to Society Better. the second classroom activities are also the process of students contacting to the society. Through a variety of social practice, practice, participate in various public welfare activities, students can have the opportunity to better understand the society, to use the knowledge to practice the second classroom activities is a process of students to participate in social activities, to cultivate students' ability of organization, self management ability, interpersonal skills, independent coping ability of various 
events and play a positive role in promoting.

The Second Classroom is an Important Way to Cultivate Innovative Talents. In the second classroom activities, college students can learn from each other and discuss together. The teacher stimulates the creative thinking of the students through cooperative inquiry, hands-on practice, judgment and reasoning, summary and so on. In such a special atmosphere in the classroom, second to stimulate the potential consciousness of innovation and entrepreneurship students, promote the development of thinking and improve their own quality, therefore the second classroom activities is an important way to cultivate innovative talents.

\section{Construction of the Second Classroom Education System Innovation Mode in Normal Universities}

Improve the Second Classroom Teaching System. In order to promote and improve college students' innovation ability training objectives, the innovation of educational practice and participate in the activities of the organic combination of decentralized innovation. We can improve the students' practical consciousness through interest groups, clubs, competitions, sports. We can improve students' cooperation and innovation consciousness through market research, cultivate interest projects design. We can enhance self-confidence, innovation and entrepreneurship students to courage, perseverance, and management, communication ability through the simulation research of entrepreneurship and field exercises.

Strengthen the Second Classroom Teacher Resources. It is an important link to improve the quality of education to strengthen the integration of the second teachers in normal colleges and universities. Therefore, we need to strengthen the second classroom teachers, equipped with more knowledge, flexible and diverse teaching methods, attention to the combination of theory and practice of excellent teachers to arrange for the second classroom guidance. Where possible, the school provides teachers with the opportunity to go out to study and train and visit, to learn the advanced educational experience and broaden their horizons. The school encourages teachers to participate in the second classroom, encourage teachers to participate in and guide the activities of the second classroom. Schools can also have a wealth of practical experience of teachers to the school for the second classroom guidance, and strive to build a high-quality, adapt to the needs of the development of teachers.

Expand the Art Practice and Improve the Art Accomplishment. Schools often carry out a variety of after-school activities to expand the practice of art. By holding the art practice, the school provides more self performance for students to demonstrate their talent. For example the calligraphy contest, national musical instrument contest, singing contest, calligraphy exhibition and skipping, badminton, basketball and other sports, let more students participate in, experience the charm of art and fun. The school also can be held by various collective activities, such as aerobics competition, collective dance competition, show the charm of the art collective, enhance students' sense of collective and cooperative consciousness. In fact, many students may have their own hobbies and some specialty, but the number one activity may be involved in the show and experience is very limited and according to this, every year or semester, large-scale activities to carry out a "campus art festival" project, a variety of different requirements, so that more students can participate in, for their confidence, so that students who are relatively lower level of ability and also can see its artistic charm and the value of existence. Focus on the process of experience, attention to the changes of each student and improve artistic accomplishment, through rich and colorful activities, let the students have more experience, feel the charm of art.

The art practice is not limited to the school, is not limited to students and teachers, it should have a broader world. Where possible, organizing students to go out to visit or study, learn advanced experience and artistic practice, often in some related arts please more prominent individuals or groups to the foreign students the school to do the performance report or presentation, hire some old artist or solid professional knowledge, artistic strong school teachers to the school for seminars, make students have a more profound understanding, for art to broaden their horizons, constantly improve their own artistic accomplishments. 
Go to the orphanage or retirement, to carry out the warmth love activities. The welfare of children are orphans or disabled, welfare is their home, to give them a piece of his own works of calligraphy and painting as a small gift, can also sing a song for them, playing a song or to they tell interesting stories, teach them to dance, gymnastics, to accompany them to do all kinds of games, which will make the children happy, you can also go to a retirement home for the elderly to do something, do all kinds of talent show for them, and even chat with them they will appreciate and moved, see these will give youth young students, light of heart from care to bring a spiritual shock, making them more cherish our happy life today, cherish everything we have. In the practice of art at the same time, was a good emotion and people The caring education. Through the Guzheng, dance performances, Guzheng the melody and dance of beauty, so that they not only have a sense of success in their artistic practice effect, especially the identification of their artistic level and self value sense, will make them better to her in the meaning, at the same time it also for a traditional cultural education.

In the study and the remaining classes, the second class is an effective means to expand the art practice. The formation of various interest groups, carry out the second classroom activities. Can be related to the music of a violin, flute, dancing group, can also be a sports aerobics, skating, walking and other teams can also be based on sketch, art of calligraphy painting, paper-cut, and other interest groups, where possible, opening speech, broadcast, Guzheng elective courses, through such activities, let more students to find their own "home", so that more people can be in a self and have common interests and hobbies in small groups, to fully display their talent, mutual learning, mutual help, solidarity and cooperation, complement each other, enrich the school life and make students more hands-on opportunities, and fully mobilize the enthusiasm of students, to improve the artistic accomplishment of an active push action use.

Organize a variety of social practice activities; enhance the sense of professional identity. It has the particularity of higher normal colleges. College students should not only learn the culture of the relevant theoretical knowledge, we should pay more attention to the quality of occupation education and learning, training of occupation identity, establish occupation thought right, to develop the correct occupation attitude and emotion oriented, the students to become a professional the level of knowledge, occupation moral good, qualified teachers emotional correct value orientation.

Some colleges and universities ignore the needs of their future work, causes the student occupation consciousness and occupation moral serious deficiencies, resulting in some of the students after graduation is difficult to adapt to the future demand for jobs, the lack of occupation identity, thus affecting the normal university personnel training. Therefore, the theme of social practice in colleges should be based on qualified teachers to cultivate all-round development, strengthen the occupation identity education for students, and make up for the lack of professional knowledge education. Close contact, the organic combination of the two, complement each other, the students become excellent teachers have certain professional level and good occupation morals.

Schools can organize students to visit the school and other various teaching activities, or to carry out for a day of teachers experience activities. Students through personal experience and investigation, to understand the teachers' work hard, appreciate their dedication and lofty occupation morality, learning their dedication spirit, so that the majority of students from by education and inspiration. And students can truly recognize as a contemporary college students, more should be down-to-earth, love will be engaged in the teacher occupation, profound experience of teacher occupation is sacred, do my best for the training of personnel.

According to the Professional Characteristics of the Investigation Team, Improve the Professional Level. The teacher's occupation is different from other industries. "The teacher is the engineer of the human soul", "the teacher is the most glorious sun occupation" and many good words are described and the occupation praise of teachers, teacher is a teacher, the teacher's words and deeds are an example for the students. As a teacher, not only to do what is more, be the same outside and inside knowledge, be familiar words. "Give students a glass of water, the teacher should have a bucket of water", that is their level of knowledge, teachers should have a good lesson, must be prepared and know many times more knowledge than this lesson, including other related the 
subject outside of the content, in order to truly ease the classroom together. Therefore, teachers' knowledge level is an important sign to measure the basic quality of teachers, but also embody the charm of Teachers As a normal college students, in the future to be engaged in the occupation of teachers, continuous learning, enrich themselves, do a good job of knowledge reserves is what every normal college students should do and must do.

According to different majors, teachers should set up a research team of different understanding, the spirit of reform and trend of education and new curriculum reform. Teachers through online Moldova class, micro class, observation and other research methods, teaching practice and teaching evaluation. Through the discussion of class, teaching content and teaching methods, and constantly improve themselves to analysis. The classroom teaching cognitive ability, learning good teachers good teaching methods and teaching methods, to understand the actual situation of the classroom teaching, age characteristics and psychological characteristics of students, understand the different levels of students to master the knowledge degree, to find the most suitable for the students of the most effective teaching mode. The teacher through the investigation to accumulate practical experience, understand the trends at home and abroad in the development of education, learning and reference experts, well-known teachers of various literature views and teaching ideas, and through common analysis, team members to explore, and In order to guide the teaching practice, we should innovate, form the text, write a paper which is in line with the characteristics of the subject, and clarify its own unique insights.

\section{Conclusion}

The second class is an important way for teacher training in normal universities; it is also a main way of quality education. The second classroom activities are rich and colorful. They not only can stimulate students' interest in learning, fully mobilize the enthusiasm of the students, but also overcomes the shortcoming of the first class is the expansion and extension of professional knowledge. The students' innovation spirit and practice ability training through second classroom activities, improve the students' ability to adapt to society, enhance the cooperation consciousness and collective ideas, promote the construction of students' own occupation accomplishment and psychological quality, and lay the necessary basis for further study and to work.

\section{Acknowledgement}

In this paper, the research was sponsored by the Educational Science Project of Jilin Province (Project No. ZC13108).

\section{References}

[1] Li Jinmin. On the cultivation of College Students' practical ability in Physical Education in local teachers colleges [J]. Education and Profession, 2014,35:144-145.

[2] Sun Hongen, Wang Changmin. Quality assurance in the construction of diversified talents training mode in Local Teachers Colleges [J]. Academic Exploration, 2015,03:152-156.

[3] Yang Liyuan, Michael. In local normal colleges "three-in-one" collaborative teacher training mode of [J]. Science Journal), 2015,05:60-61.

[4] Liao Jingwei normal primary education majors. Art class "interest" teaching method of [D]. Hunan Normal University, 2015

[5] Kang Jingyu. A study on the teaching mode of the combination of big and small piano in Normal Universities [D]. Guangxi Normal University, 2015

[6] Gao Yiyuan. Study on the cultivation mode of humanistic quality education in Higher Vocational Colleges [D]. Kunming University of Science and Technology, 2016 
[7] Zhang Songqing, Yu Zhenhua. Discussion on the training mode of students' ability in Local Universities [J]. Journal of Shaoyang University, 2013,01:107-112. 